\title{
Geology and Assessment of Undiscovered Oil and Gas Resources of the Tunguska Basin Province, 2008
}

Chapter $\mathrm{U}$ of

The 2008 Circum-Arctic Resource Appraisal

Professional Paper 1824

U.S. Department of the Interior

U.S. Geological Survey 
Eocene strata along the north side of Van Keulenfjorden, Svalbard, include basin-floor fan, marine slope, and deltaic to fluvial depositional facies. The age and facies of these strata are similar to Tertiary strata beneath the continental shelves of Arctic Eurasia, thus providing an analog for evaluating elements of those petroleum systems. Relief from sea level to top of upper bluff is approximately 1,500 feet. Photograph by David Houseknecht. 


\section{Geology and Assessment of Undiscovered Oil and Gas Resources of the Tunguska Basin Province, 2008}

By Craig J. Wandrey and Timothy R. Klett

Chapter U of

The $\mathbf{2 0 0 8}$ Circum-Arctic Resource Appraisal

Edited by T.E. Moore and D.L. Gautier

Professional Paper 1824 


\section{U.S. Department of the Interior RYAN K. ZINKE, Secretary}

\section{U.S. Geological Survey James F. Reilly II, Director}

\section{U.S. Geological Survey, Reston, Virginia: 2018}

For more information on the USGS - the Federal source for science about the Earth, its natural and living resources, natural hazards, and the environment-visit https://www.usgs.gov or call 1-888-ASK-USGS.

For an overview of USGS information products, including maps, imagery, and publications, visit https://store.usgs.gov.

Any use of trade, firm, or product names is for descriptive purposes only and does not imply endorsement by the U.S. Government.

Although this information product, for the most part, is in the public domain, it also may contain copyrighted materials as noted in the text. Permission to reproduce copyrighted items must be secured from the copyright owner.

Suggested citation:

Wandrey, C.J., and Klett, T.R., 2018, Geology and assessment of undiscovered oil and gas resources of the Tunguska Basin Province, 2008, chap. U of Moore, T.E., and Gautier, D.L., eds., The 2008 Circum-Arctic Resource Appraisal: U.S. Geological Survey Professional Paper 1824, 10 p., https://doi.org/10.3133/pp1824U.

ISSN 2330-7102 (online) 


\section{The 2008 Circum-Arctic Resource Appraisal}

\section{Chapters}

A. Introduction to the 2008 Circum-Arctic Resource Appraisal (CARA) Professional Paper By Donald L. Gautier and Thomas E. Moore

B. Methodology for Assessment of Undiscovered Oil and Gas Resources for the 2008 Circum-Arctic Resource Appraisal

By Ronald R. Charpentier

\section{North America}

C. Geology and Assessment of Undiscovered Oil and Gas Resources of the Chukchi Borderland Province, 2008

By Kenneth J. Bird and David W. Houseknecht

D. Geology and Assessment of Undiscovered Oil and Gas Resources of the Hope Basin

Province, 2008

By Kenneth J. Bird, David W. Houseknecht, and Janet K. Pitman

E. Geology and Assessment of Undiscovered Oil and Gas Resources of the Arctic Alaska Petroleum Province, 2008

By David W. Houseknecht, Kenneth J. Bird, and Christopher P. Garrity

F. Geology and Assessment of Undiscovered Oil and Gas Resources of the Yukon Flats Basin Province, 2008

By Kenneth J. Bird and Richard G. Stanley

G. Geology and Assessment of Undiscovered Oil and Gas Resources of the Northwest Canada Interior Basins Province, Arctic Canada, 2008

By Marilyn E. Tennyson and Janet K. Pitman

H. Geology and Assessment of Undiscovered Oil and Gas Resources of the Franklinian Shelf Province, Arctic Canada and North Greenland, 2008

By Marilyn E. Tennyson and Janet K. Pitman

I. Geology and Assessment of Undiscovered Oil and Gas Resources of the Sverdrup Basin Province, Arctic Canada, 2008

By Marilyn E. Tennyson and Janet K. Pitman

\section{Greenland}

J. Geology and Assessment of Undiscovered Oil and Gas Resources of the West GreenlandEast Canada Province, 2008

By Christopher J. Schenk 
K. Geology and Assessment of Undiscovered Oil and Gas Resources of the East Greenland Rift Basins Province, 2008

By Donald L. Gautier

\section{North Atlantic Ocean}

L. Geology and Assessment of Undiscovered Oil and Gas Resources of the Jan Mayen Microcontinent Province, 2008

By Thomas E. Moore and Janet K. Pitman

\section{Eurasia}

M. Geology and Assessment of Undiscovered Oil and Gas Resources of the Mezen' Basin Province, 2008

By Timothy R. Klett and Janet K. Pitman

N. Geology and Assessment of Undiscovered Oil and Gas Resources of the Timan-Pechora Basin Province, Russia, 2008

By Christopher J. Schenk

0. Geology and Assessment of Undiscovered Oil and Gas Resources of the East Barents Basins Province and the Novaya Zemlya Basins and Admiralty Arch Province

By Timothy R. Klett

P. Geology and Assessment of Undiscovered Oil and Gas Resources of the North Kara Basins and Platforms Province, 2008

By Timothy R. Klett and Janet K. Pitman

0. Geology and Assessment of Undiscovered Oil and Gas Resources of the Northern West Siberian Mesozoic Composite Total Petroleum System of the West Siberian Basin Province, Russia, 2008

By Christopher J. Schenk

R. Geology and Assessment of Undiscovered Oil and Gas Resources of the Yenisey-Khatanga Basin Province, 2008

By Timothy R. Klett and Janet K. Pitman

S. Geology and Assessment of Undiscovered Oil and Gas Resources of the Northwest Laptev Sea Shelf Province, 2008

By Timothy R. Klett and Janet K. Pitman

T. Geology and Assessment of Undiscovered Oil and Gas Resources of the Lena-Anabar Basin Province, 2008

By Timothy R. Klett and Janet K. Pitman 
U. Geology and Assessment of Undiscovered Oil and Gas Resources of the Tunguska Basin Province, 2008

By Craig J. Wandrey and Timothy R. Klett

V. Geology and Assessment of Undiscovered Oil and Gas Resources of the Lena-Vilyui Basin Province, 2008

By Timothy R. Klett and Janet K. Pitman

W. Geology and Assessment of Undiscovered Oil and Gas Resources of the Laptev Sea Shelf Province, 2008

By Timothy R. Klett and Janet K. Pitman

X. Geology and Assessment of Undiscovered Oil and Gas Resources of the Zyryanka Basin Province, 2008

By Timothy R. Klett and Janet K. Pitman

Y. Geology and Assessment of Undiscovered Oil and Gas Resources of the East Siberian Sea Basin Province, 2008

By Kenneth J. Bird, David W. Houseknecht, and Janet K. Pitman

Z. Geology and Assessment of Undiscovered Oil and Gas Resources of the Vilkitskii Basin Province, 2008

By Kenneth J. Bird, David W. Houseknecht, and Janet K. Pitman

AA. Geology and Assessment of Undiscovered Oil and Gas Resources of the Long Strait Province, Russian High Arctic, 2008

By Kenneth J. Bird, David W. Houseknecht, and Janet K. Pitman

\section{Arctic Ocean}

BB. Geology and Assessment of Undiscovered Oil and Gas Resources of the Amerasia Basin Petroleum Province, 2008

By David W. Houseknecht, Kenneth J. Bird, and Christopher P. Garrity

CC. Geology and Assessment of Undiscovered Oil and Gas Resources of the LomonosovMakarov Province, Central Arctic Ocean, 2008

By Thomas E. Moore, Kenneth J. Bird, and Janet K. Pitman

DD. Geology and Assessment of Undiscovered Oil and Gas Resources of the Eurasia Basin Province, Eastern Arctic Ocean, 2008

By Thomas E. Moore and Janet K. Pitman 


\section{Contents}

Abstract

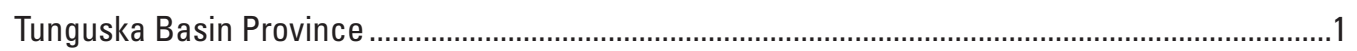

Province Boundary Definitions................................................................................................

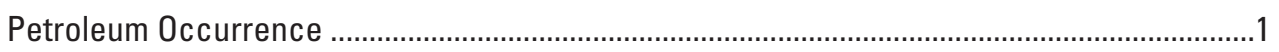

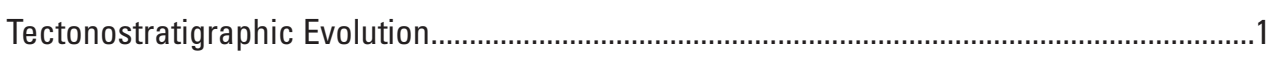

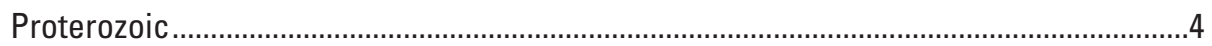

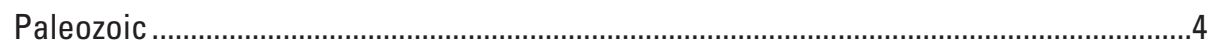

Mesozoic and Cenozoic .....................................................................................................

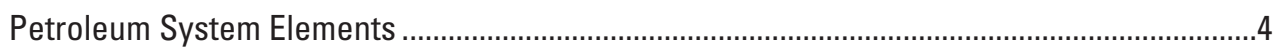

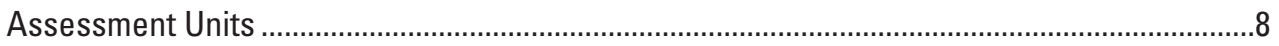

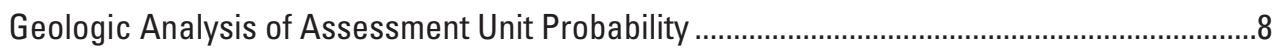

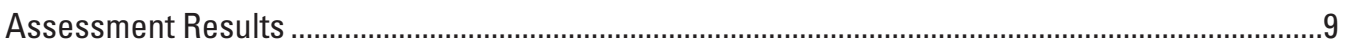

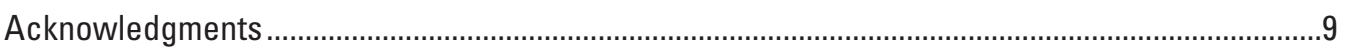

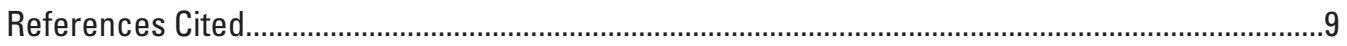

\section{Appendix}

[Available for download at https://doi.org.10.3133/pp1824U]

1. Input data for the Tunguska Basin Assessment Unit

\section{Figures}

1. Map showing location of province and assessment units.

2. Structural map showing major structural features and approximate depth to economic basement in the Laptev Sea Shelf Province ......................................................................

3. Regional geologic cross sections ............................................................................................. 4

4. Lithostratigraphic column and total petroleum system events chart.........................................5

5. Burial history model for pseudowells in the West Laptev Grabens Assessment Unit depicting thermal maturity 


\title{
Chapter U
}

\section{Geology and Assessment of Undiscovered Oil and Gas Resources of the Tunguska Basin Province, 2008}

\author{
By Craig J. Wandrey and Timothy R. Klett
}

\section{Abstract}

The U.S. Geological Survey (USGS) has evaluated the potential for undiscovered oil and gas resources of the Tunguska Basin Province as part of the Circum-Arctic Resource Appraisal (CARA). The Tunguska Basin Province includes an area of approximately $904,000 \mathrm{~km}^{2}$; less than half the area of the province lies north of the Arctic Circle. The Tunguska Basin Province includes a large part of the Siberian craton and consists of several subbasins. The province is almost completely covered by Permian to Triassic volcanic rocks. Although some oil and gas fields have been discovered and produced in the province south of the Arctic Circle, no discoveries have been made north of the Arctic Circle as of 2008. The part of this province lying north of the Arctic Circle was evaluated for undiscovered, technically recoverable, conventional oil and gas resources. Because of a low geologic probability for the occurrence of significant oil and gas accumulations (50 million barrels of oil equivalent or more), the Tunguska Basin Province north of the Arctic Circle was not quantitatively assessed as part of CARA.

\section{Tunguska Basin Province}

This chapter describes the data and reasoning used by the U.S. Geological Survey (USGS) to evaluate undiscovered, technically recoverable conventional petroleum resources in a portion of of the Tunguska Basin Province north of the Arctic Circle. Here we synthesize results of previous studies and recast the geologic models in light of petroleum system elements.

\section{Province Boundary Definitions}

The Tunguska Basin Province includes an area of approximately $904,000 \mathrm{~km}^{2}$ and less than half of that area lies north of the Arctic Circle (fig. 1). The Turukhan-Norilsk Folded Zone Province and the eastern part of the Turukhan-Igarka Uplift Province, along the western boundary of the Tunguska Basin, were included in this assessment. The Tunguska Basin
Province, which constitutes a large part of Siberian craton, and several subbasins, is almost completely covered by Permian to Triassic volcanic rocks (which constitute trap deposits). Where exposed, the stratigraphic section ranges in age from Proterozoic (Riphean) to Paleozoic (Devonian), with Triassic and possibly older igneous sills present throughout the stratigraphic section above the Proterozoic (Riphean and Vendian) rocks. Volcanic rocks comprise as much as 25 percent of the section. Near the western and eastern basin margins, the volcanic rocks have been eroded, exposing Cambrian to Devonian rocks. The province borders the Yenisey-Khatanga Basin Province to the north, the Turukhan-Igarka Uplift Province and Yenisey Ridge Province to the west, Baykit High Province to the south, and the Anabar-Olenek High Province and Nepa-Botouba High Province to the east (fig.1).

\section{Petroleum 0ccurrence}

In the Tunguska Basin Province, five gas and condensate fields have been discovered in Proterozoic rocks, but these fields are all south of the Arctic Circle and therefore not considered part of the Circum-Arctic Resource Appraisal area. The Volodinskoye gas and condensate field in the TurukhanNorilsk Folded Zone, along the western boundary of the Tunguska Basin Province, was the first discovery in the province. Five gas and gas/condensate fields, and one oil field, were discovered before 1990 on anticlines and monoclines. No oil or gas discoveries had yet been made north of the Arctic Circle at the time of the CARA evaluations (2008).

\section{Tectonostratigraphic Evolution}

The Siberian craton consists of crystalline rocks and overlying Proterozoic sedimentary rocks deposited in intracratonic rifts (Ulmishek, 2001a). The Tunguska Basin developed on the Siberian craton as a late Proterozoic to Paleozoic sag basin over rifts (fig. 2). Paleozoic rocks, mainly carbonates, were deposited along the margins of the craton and are overlain by a progressively outward-thickening Mesozoic section (Persits and others, 1998; Persits and Ulmishek, 2003).

The Siberian craton was located in low and equatorial latitudes throughout the Proterozoic and early Paleozoic, with 


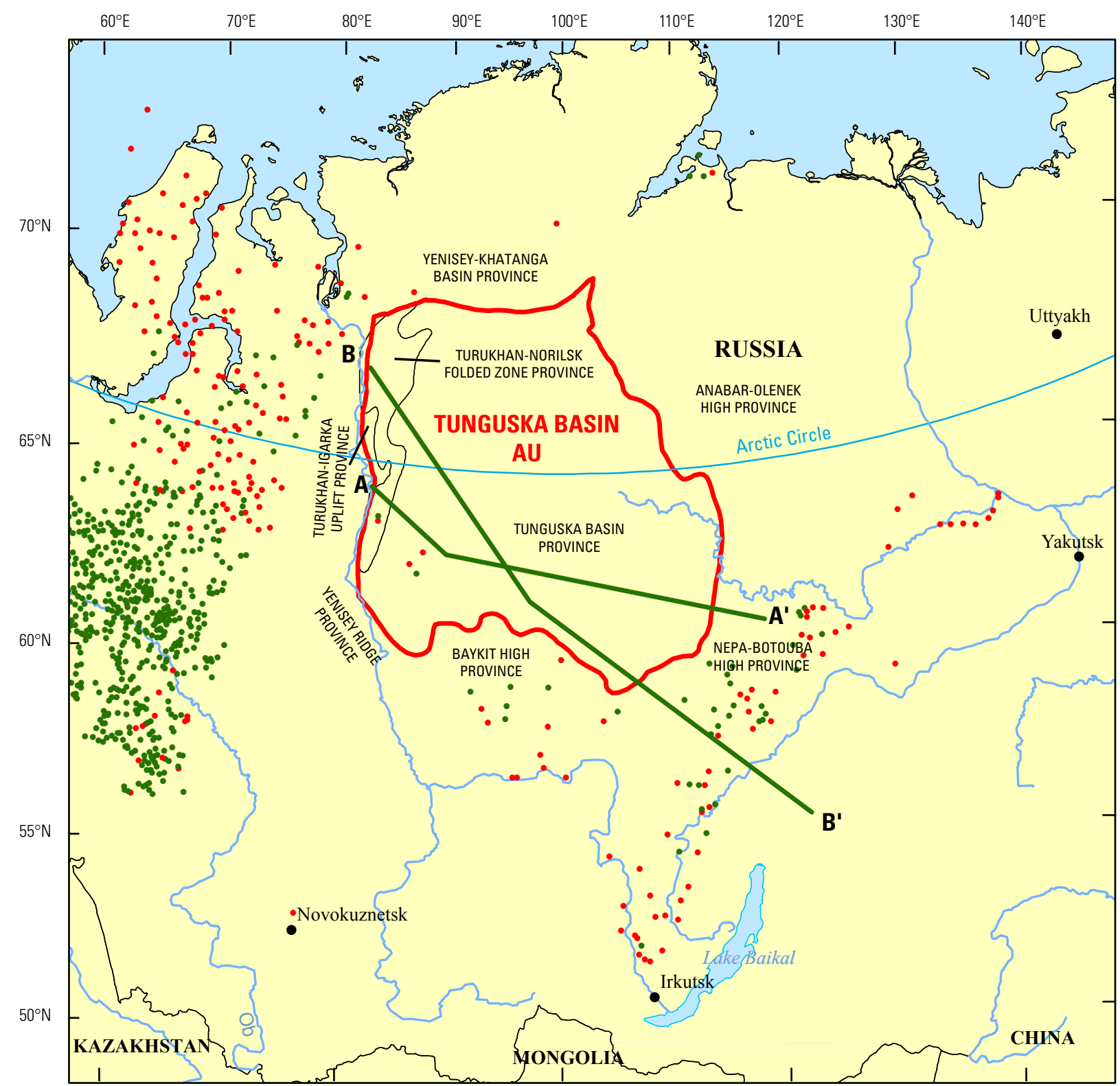

Figure 1. Map showing location of Tunguska Basin Province and surrounding geologic provinces Proterozoic-Silurian Composite Total Petroleum System and Tunguska Basin Assessment Unit (AU) (red outline), location of cross sections shown in figure 3 (green lines), and centerpoints of oil and gas fields (green and red dots, respectively). Oil and gas field locations from IHS Energy Group (2007). 


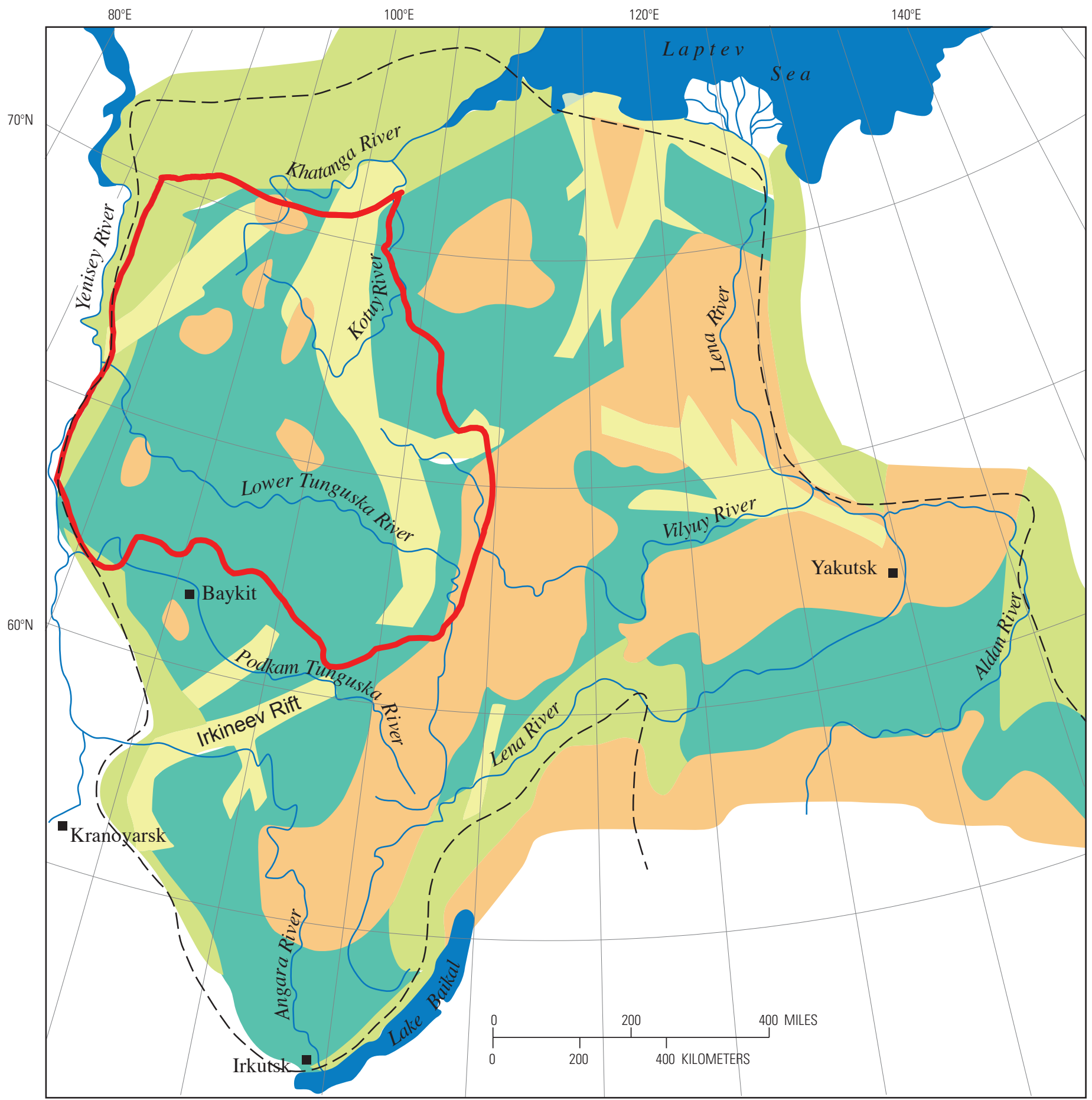

\section{EXPLANATION}
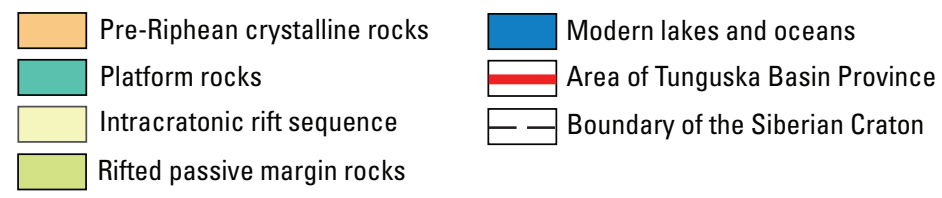

Figure 2. Map showing the distribution of Riphean rocks of the Siberian craton beneath the pre-Vendian unconformity, modified from Kuznetsov (1997) and Ulmishek (2001a, b). 
the present-day northern margin facing south. The craton drifted northward to between 50 to 70 degrees north latitude from the Devonian to the Triassic, and it rotated clockwise to its present orientation throughout the Mesozoic (Zonenshain and others, 1990).

The development of petroliferous areas of the Siberian craton, such as the Tunguska Basin, was a result of deposition of passive margin sediments that later went through several episodes of extension and compression. Major extensional events occurred during the late Proterozoic (early Riphean) and Devonian. Major plate collisions occurred during the early Paleozoic, Permian, and late Mesozoic.

\section{Proterozoic}

The basement of the entire Siberian craton is composed of Archean to lower Proterozoic crystalline rocks (Ulmishek, 2001a). Intracratonic extension and rifting occurred during late Proterozoic time (Riphean), along with deposition of as much as $10 \mathrm{~km}$ of carbonate and clastic sediments (Kuznetsov, 1997). Sediments were thickest along the passive continental margins of the Siberian craton and thinner elsewhere.

Uplift, deformation, and erosion during late Proterozoic time resulted in an angular unconformity within the Proterozoic section, between Riphean and overlying Vendian rocks (Zonenshain and others, 1990; Ulmishek, 2001a). Clastic sediments were deposited in the lower part of the Vendian section, and transitioned upward into primarily carbonate rocks. The upper part of the Vendian section is truncated by an unconformity and is represented by a thin interval of carbonate rocks that include dolostone and localized beds of anhydrite.

Uplift isolated the southern part of the Siberian craton, allowing a large shallow lagoon to develop during the late Vendian and Early Cambrian, into which evaporites were deposited (figs. 3,4 ). The lagoon was rimmed by carbonate shelves on the present-day southeastern and southwestern margins of the craton, and separated from the open ocean by reefs along the present-day north and northeast margins (Astashkin and others, 1984; Gogina and Leonov, 1983; Bakhturov and others, 1990; Ulmishek, 2001a).

\section{Paleozoic}

Carbonate platform and shelf conditions continued on the Siberian craton and along the rifted passive margins into the early Paleozoic. Lower and Middle Cambrian rocks include alternating beds of dolostone, salt (halite), and anhydrite as a result of episodic subaerial exposure (Ulmishek, 2001a). Organic-rich (bituminous) mudstone was deposited beyond the reefs in the north and northeast part of the craton during the Early and Middle Cambrian. The Upper Cambrian interval contains dolostone with anhydrite, and clastic rocks. Ordovician rocks are primarily carbonates in the lower part of the section, grading to mostly clastic rocks in the upper part and into the Silurian section. Younger Paleozoic rocks are absent across most of the Siberian craton because of nondeposition and erosion (Ulmishek, 2001a). The southern and interior parts of the craton remain elevated.

The Siberian craton drifted northward during the Devonian to Triassic (Zonenshain and others, 1990). During the Devonian, the craton passed over a mantle plume (hot spot), causing rifting and magmatism along the present-day eastern and northern margins of the craton. Carbonate and evaporite rocks were deposited in the rifts, where organic-rich mudstone could have been deposited prior to evaporite deposition (Ulmishek, written commun., 2006).

As the Siberian craton drifted northward, it moved from a warm dry climate at low to middle latitudes into a cooler humid climate at higher latitudes. The margins of the craton remained passive during the late Paleozoic and into the early Mesozoic, and thick successions of deltaic, paralic, nearshore marine, and submarine fan strata were deposited along the margins. Silurian and younger Paleozoic rocks thin upward or are absent (fig. 3).

\section{Mesozoic and Cenozoic}

During the late Permian to Early Triassic, collision of the Siberian craton and Kazakh Plate with the East European craton deformed the western edge of the Siberian craton from the Yenisey Ridge to the Turukhan-Igarka Uplift and formed the Turukhan-Norilsk Folded Zone (Ulmishek, 2001b).

Extension, magmatism, and volcanism occurred during the Permian and Triassic, and a triple junction formed along the present-day northwest margin of the Siberian craton (Allen and others, 2006). Rifting resulted in the emplacement of flood basalts across the Tunguska Basin and igneous sills within the stratigraphic section (fig. 4). A central basin developed in the Mesozoic section of the Siberian craton. A regional sag developed during the Triassic and Jurassic into which clastic rocks were deposited. Episodic uplift during the Mesozoic and Cenozoic inverted grabens and caused much of the postTriassic sedimentary cover to erode. Tectonic movements and uplift resumed during the Neogene, forming the present-day dissected topography across the province (Ulmishek, 2001a) (fig. 3).

\section{Petroleum System Elements}

A Proterozoic-Silurian composite total petroleum system (TPS) was identified in the Tunguska Basin Province. The TPS name implies that potential source and reservoir rocks occur in both Proterozoic and Paleozoic (up to Silurian) stratigraphic successions. Most of the Mesozoic section in the assessed area is absent. Seal rocks, traps, and timing are also elements of the TPS. A lithostratigraphic column and events chart for the TPS is shown in figure 5. The Proterozoic-Silurian Composite TPS encompasses the Tunguska Basin, the Turukhan-Norilsk Folded Zone Province, and the eastern part of the TurukhanIgarka Uplift Province (fig. 1). 


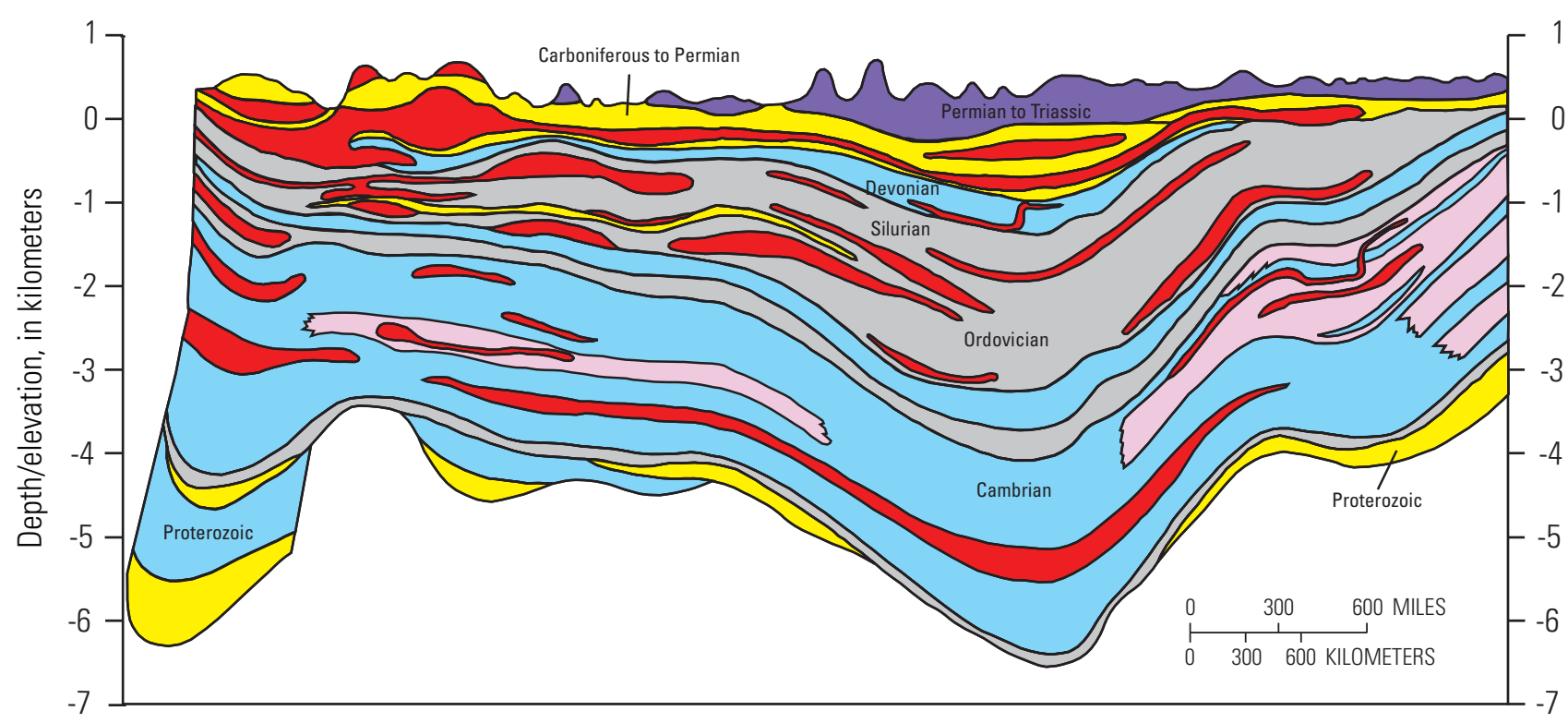

$B$

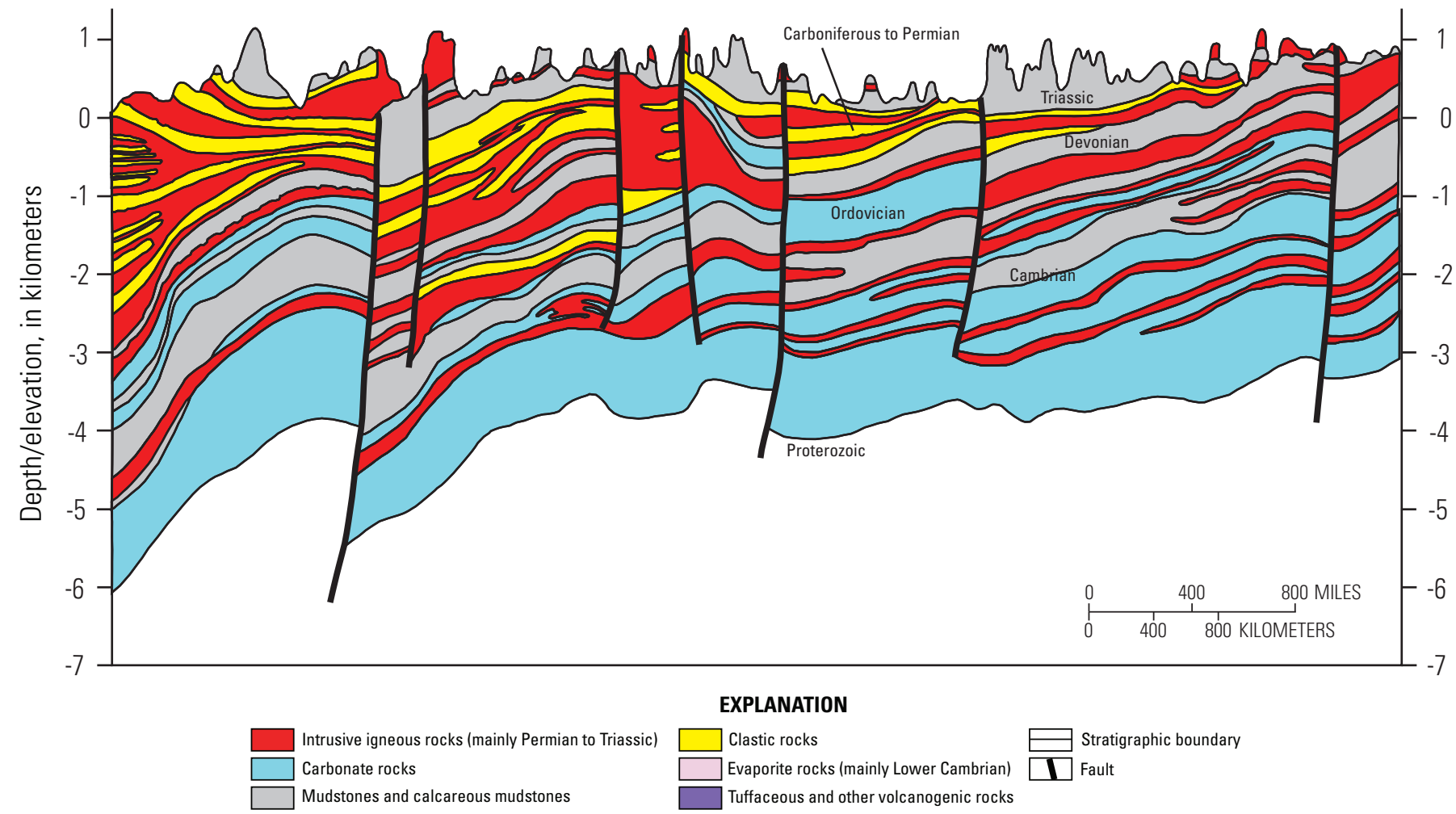

Figure 3. Schematic regional geologic cross sections (A-A' and B-B') through the Tunguska Basin Province. Locations of cross sections are shown in figure 1. Modified from Kontorovich and others (1997). 


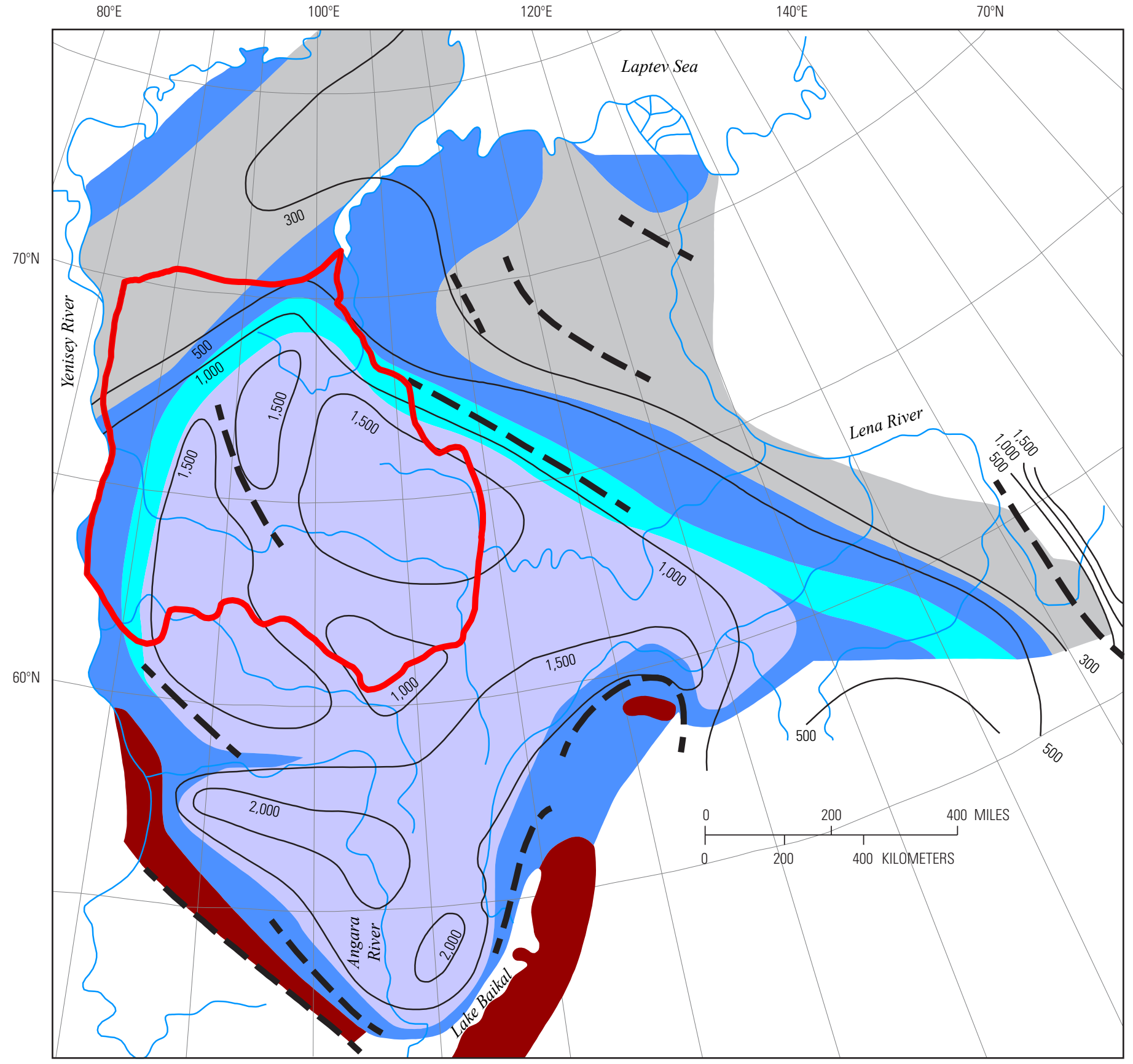

\section{EXPLANATION}

\begin{tabular}{|c|c|c|c|}
\hline Evaporite lagoon & Deep-water, organic-rich mudstones and carbonates & 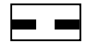 & Synsedimentary faults \\
\hline Reef zone & Land & 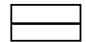 & Isopachs, labels in meters \\
\hline Carbonate shelf & Modern rivers and shoreline & & Area of Tunguska Basin Province \\
\hline
\end{tabular}

Figure 4. Paleogeographic map of the Siberian craton during Early Cambrian and early Middle Cambrian, modified from Gabrielyants (1991) and Ulmishek (2001a, b). 


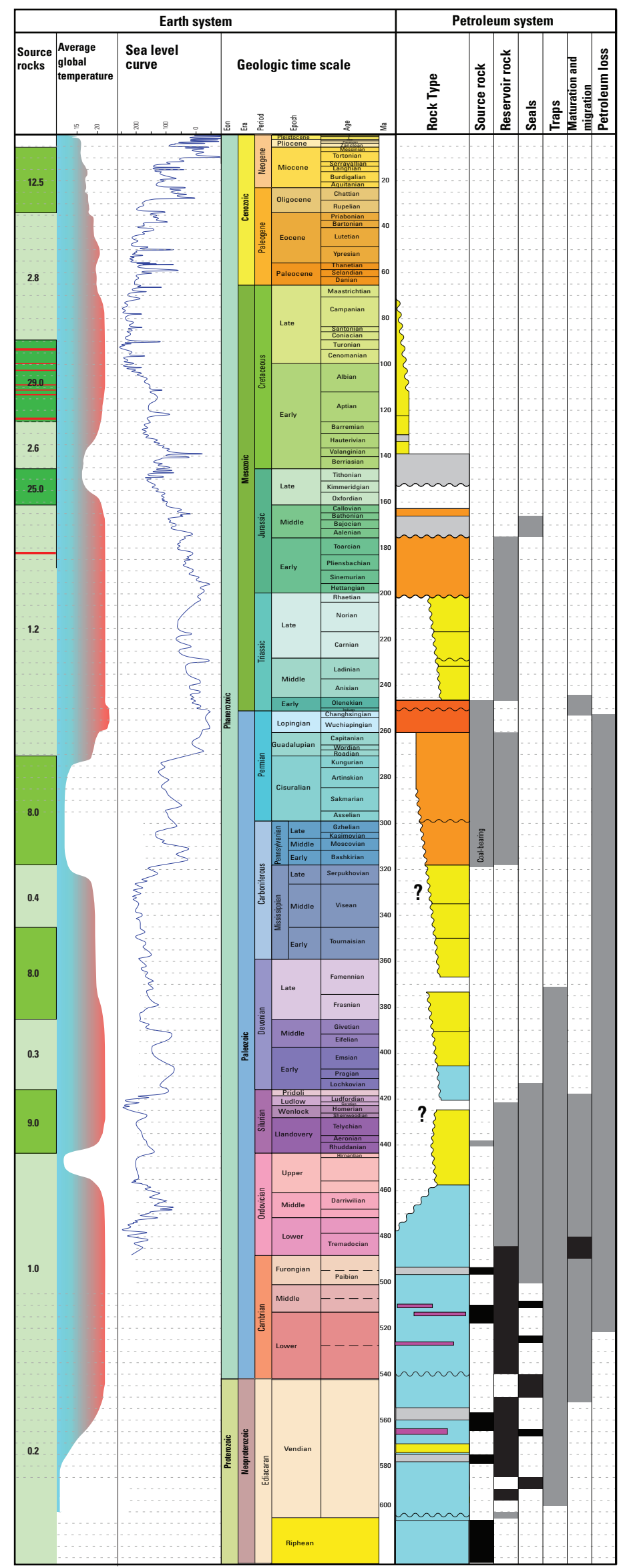

Figure 5. Lithostratigraphic column and total petroleum system events chart showing petroleum system elements for the Tunguska Basin Province. Data from Bobilev (1985), Filipiov and others (1999), Grausman (1996), Kontorovich and others (1994), Lebchuk (1990), Shenfil' (1991), Shishkin and Isaev (1999), and Surkova (1987). Source rocks column shows the percent of the world's total petroleum reserves generated by source (modified from Ulmishek and Klemme, 1990). Average global temperature data is from Frakes and others (1992) and Barrett (2003). Sea level curve is from Golonka and Kiessling (2002) and Hardenbol and others (1998). Geologic time scale is that of Gradstein and others (2004). Geologic chart designed by P.J. McCabe (written commun., 2006).

\begin{tabular}{|c|}
\hline EXPLANATION \\
Rock Type \\
$\square$ Continental clastic rocks \\
$\square$ Nearshore clastic rocks \\
$\square$ Offshore clastic rocks \\
$\square$ Evaporites \\
$\square$ Volcanic rocks \\
$\square$ Carbonate rocks \\
Petroleum system \\
Identified presence \\
$\square$ Possible presence \\
- Ocean anoxic event \\
\hline
\end{tabular}


Source Rocks.-Presumed source rocks in the Proterozoic-Silurian Composite TPS include Riphean, Vendian, and Cambrian mudstones, as inferred by the presence of petroleum that was generated by similar source rocks in the southeastern portion of the Siberian craton (Kashirtsev and others, 1997). Geochemical source rock to petroleum correlations within the Tunguska Basin Province, however, were not available for this study. Riphean mudstones are relatively widespread and have total organic carbon (TOC) contents averaging from 1.2 to 1.9 weight percent and as high as 7 to 8 weight percent (Kuznetsov, 1997). Vendian mudstones are reported to have generated hydrocarbons elsewhere on the Siberian craton (Bakhturov, 1985; Ulmishek, 2001a) and they might have generated hydrocarbons within the TPS. Riphean and Vendian source rocks probably became thermally mature for petroleum generation during the early Paleozoic. Cambrian mudstones may have also generated hydrocarbons if they became thermally mature.

Reservoir and Seal Rocks.-Potential reservoir rocks in the Proterozoic-Silurian composite TPS include Riphean carbonates, Vendian dolostones and sandstones (up to $50 \mathrm{~m}$ thick), and Upper Cambrian cavernous and fractured dolostones (4 to $70 \mathrm{~m}$ thick) (Kontorovich and others, 1997). The porosity of the sandstone is as much as 20 percent, and permeability ranges from hundreds to thousands of millidarcies (Kuznetsov, 1997). Seals could potentially be Riphean argillaceous limestones, about $100 \mathrm{~m}$ thick, and Vendian evaporite rocks. Thick salt is present in only the southernmost part of the basin. Faults, mudstone, and localized salt also provide seals.

Traps and Timing.-Within the Proterozoic-Silurian composite TPS, a large part of the stratigraphic section is missing because of nondeposition or erosion. Eroded or missing sections are identified in Vendian and Cambrian or Ordovician to Triassic rocks. Triassic and younger rocks are also absent over much of the province, because the province has been a slightly positive feature since the Triassic.

Various types of traps are present in the ProterozoicSilurian composite TPS and include anticlines and faulted anticlines, fault blocks, updip pinchouts in sags and on monoclines, stratigraphic traps, paleochannels eroded into Cambrian carbonate rocks, and grabens that developed as failed rifts from the early Vendian to Devonian. Oil and gas discoveries to date are all associated with anticlines and monoclines (IHS Energy Group, 2007). The timing of trap formation is early Vendian to Devonian. Permian and Triassic rifting could have created efficient traps, but rifting events occurred after primary petroleum generation and migration.

\section{Assessment Units}

Only one assessment unit (AU) was defined for this province, the Tunguska Basin AU, which was not quantitatively assessed for the reasons described below. The boundary of the
Tunguska Basin AU coincides with the Proterozoic-Silurian Composite TPS boundary (fig. 1). Thirty-nine percent of the Tunguska Basin AU is north of the Arctic Circle and 100 percent of the province's area is onshore. The stratigraphic section includes upper Proterozoic (Riphean) to Mesozoic sedimentary rocks, including several unconformities, and volcanic rocks.

Significant quantities of hydrocarbons might have been generated within the Proterozoic-Silurian Composite TPS, but the timing of trap development after early Paleozoic petroleum generation and the absence of evaporite rock seals in much of the AU suggests that there is little, if any, oil or gas present in the Tunguska Basin Province north of the Arctic Circle. Evaporite rocks that can provide a seal south of the Tunguska Basin AU are only thick enough to be effective in the southern part of the AU. Emplacement of igneous sills during the Permian through Triassic might have cracked oil to gas, which could have possibly escaped.

\section{Geologic Analysis of Assessment Unit Probability}

As of 2007, three gas fields and two oil fields with reported recoverable volumes of less than 50 million barrels oil equivalent (MMBOE) have been discovered in the Tunguska Basin AU, none of which are north of the Arctic Circle (IHS Energy Group, 2007; fig. 1). Three elements of geologic risk are incorporated in an AU probability for quantitative assessment: (1) adequate charge (quantity) of generated petroleum; (2) adequate reservoir and seal rocks for petroleum accumulation; and (3) adequate timing of petroleum maturation with respect to trap formation. Only AUs with a probability of 0.10 (10 percent) or more for existence of one field anywhere in the AU equal to or greater than the minimum field size of $50 \mathrm{MMBOE}$ for quantitative assessment of undiscovered petroleum resources are quantitatively assessed. The estimated AU probabilities and the reasons for these estimates are listed below and reported in appendix 1.

Charge Probability - A charge probability of 0.8 is estimated because source rocks in this AU have not been identified and might not exist.

Rocks Probability - A rock probability of 0.7 is estimated because the presence and quality of reservoir and seal rocks in the AU are not known and might not be adequate.

Timing and Preservation Probability-A timing and preservation probability of 0.1 is estimated for this AU because of the possible lack of oil and gas retention caused by episodic uplift and erosion that had taken place following early Paleozoic generation.

The product of the estimated AU probabilities $(0.8 \times 0.7$ $x$ 0.1) of this AU is 0.056 (5.6 percent), below the threshold for a full assessment, and therefore the Tunguska Basin AU was not quantitatively assessed. 


\section{Assessment Results}

Although some oil and gas discoveries and production occur in the Tunguska Basin AU south of the Arctic Circle, no discoveries have been made inside the Arctic Circle at the time of this study. Because of a low geologic probability for the presence of oil and gas accumulations containing $50 \mathrm{MMBOE}$ or more, the Tunguska Basin AU was not quantitatively assessed.

\section{Acknowledgments}

The authors would like to acknowledge F.M. Persits for GIS support, and D.L. Gautier and G.F. Ulmishek for their valuable comments. The authors are grateful to the USGS library staff for their help in obtaining hard-to-find and rare geologic articles from the Russian scientific literature.

\section{References Cited}

Allen, M.B., Anderson, L., Searle, R.C., and Buslov, M., 2006, Oblique rift geometry of the West Siberian Basin: tectonic setting for the Siberian flood basalts: Journal of the Geological Society, London, v. 163, p. 901-904.

Astashkin, V.A., Varlamov, A.I., Gubina, N.K., Ekhanin, A.E., Pereladov, V.S., Romenko, V.I., Sukhov, S.S., Umperovich, N.V., Fedorov, A.B., Feyyanin, A.P., Shishkin, B.B., and Khobnya, E.I., 1984, Geologiya i perspectivy neftegazonosnosti rifovykh sistem kembtiya Sibirskoi platformy (Geology and prospects of oil-gas-bearing of the Cambrian reef systems of the Siberian Platform): Moscow, Nedra, 181 p. (in Russian).

Bakhturov, S.F., 1985, Bituminoznye karbonatno-slantsevye formatsii Vostochnoy Sibiri (Bituminous carbonate-shale formations of eastern Siberia): Trudy Instituta Geologii i Geofiziki, no. 617, Sibirskoye Otdelenie, Akademiya Nauk SSSR, 126 p. (in Russian).

Bakhturov, S.F., Yevtushenko, V.M., Pereladov, V.S., 1990, Kuonam bituminous carbonate shale complex: Petroleum Geology, v. 24, no. 3-4, p. 124-133, translated from Trudy Instituta Geologii i Geofiziki, no. 671, Sibirskoye Otdelenie, Akademiya Nauk SSSR, 160 p., 1988.

Barrett, P., 2003, Paleoclimatology: cooling a continent: Nature, v. 421, p. 221-223.

Bobilev, V.V., 1985, Cyclic pattern of the Mesozoic-Cenozoic mega-complex of the North of the Siberian platform: Spesifichnost' geologicheskikh usloviy I neftegasonosnosti Sibiri pri biborenapravleniy poiskovo-rasvedochnihk rabot, Moscow, VNIGRI (In Russian).
Clarke, J.W., 1991, Petroleum geology of East Siberia [abs.]: American Association of Petroleum Geologists Bulletin, v. 75, no. 3, p. 554 (presented at the 1991 American Association of Petroleum Geologists Annual Convention, Dallas, Texas, 7-10 April).

Filipiov, Yu.A., Boldushevskaya, L.N., Kontorovich, A.A., Krinin,V.A., and Fomin, A.N., 1999, Catagenesis of organic matter and phase and phase composition of hydrocarbon pools of northwest frame of Siberian Craton: Petroleum Geology, v. 33, no. 4, p. 359-370, translated from Geologiya Nefti i Gaza, no. 12, p. 25-33, 1998.

Frakes, L.A., Francis, J.E., and Syktus, J.I., 1992, Climate modes of the Phanerozoic: the history of the earth's climate over the past 600 million years: Cambridge University Press, Cambridge, 274 p.

Gabrielyants, G.A., ed., 1991, Regional geology of petroleum provinces of the USSR (Regionalnaya Geologiya neftegazonosnykh territoriy SSSR): Moscow, Nedra, 284 p.

Gogina, N.I., and Leonov, B.N., 1983, Cambrian reefs around the lower reaches of the Lena River: Geologiya i Geofizika, v. 24, no. 9, p. 87-91 (p. 94-98 in Russian).

Golonka, J., and Kiessling, W., 2002, Phanerozoic time scale and definition of time slices, in Kiessling, W., Flügel, E., and Golonka, J., eds., Phanerozoic reef patterns: Society of Economic Paleontologists and Mineralogists Special Publication 72, p. 11-20.

Gradstein, F.M., Ogg, J.G., and Smith, A.G., Agterberg, F.P., Bleeker, W., Cooper, R.A., Davydov, V., Gibbard, P., Hinnov, L.A., House, M.R., Lourens, L., Luterbacher, H.P., McArthur, J., Melchin, M.J., Robb, L.J., Shergold, J., Villeneuve, M., Wardlaw, B.R., Ali, J., Brinkhuis, H., Hilgen, F.J., Hooker, J., Howarth, R.J., Knoll, A.H., Laskar, J., Monechi, S., Plumb, K.A., Powell, J., Raffi, I., Röhl, U., Sadler, P., Sanfilippo, A., Schmitz, B., Shackleton, N.J., Shields, G.A., Strauss, H., Van Dam, J., van Kolfschoten, T., Veizer, J., and Wilson, D., 2004, A geologic time scale: Cambridge University Press, 589 p.

Grausman, V.V., 1996, Upper Precambrian deposits of the Olenek Uplift from deep drilling data: Tikhookeanskaya Geologiya, v. 12 , no. 4, p. 775-781.

Hardenbol, J., Thierrt, J., Farley, M.B., Jacquin, T., de Graciansky, P.-C., and Vail, P.R., 1998, Mesozoic and Cenozoic sequence chronostratigraphic framework for European basins, in de Graciansky, P.-C., Hardenbol, J., Jacquin, T., and Vail, P.R., eds., Mesozoic and Cenozoic sequence stratigraphy of European basins: Society of Economic Paleontologists and Mineralogists Special Publication 60, p. 3-13. 
IHS Energy Group, 2007 [includes data current through October 2007], International exploration and production database: Englewood, Colo., IHS Energy Group [database available from IHS Energy Group, 15 Inverness Way East, D205, Englewood, CO 80112, U.S.A].

Kashirtsev, V.A., Philp, R.P., Chalaya, O.N., Zueva, I.N., and Trushcheleva, G.S., 1997, Genetic petroleum families of the eastern Siberian platform: Otechestvennaya Geologiya, no. 8, p. 28-30.

Khudoley, A.K., Kropachev, A.P., Tkachenko, V.I., Rublev, A.G., Sergeev, S.A., Matukov, D.I., and Lyahnitskaya, O.Yu., 2007, Mesoproterozoic to Neoproterozoic evolution of the Siberian Craton and adjacent microcontinents: An overview with constraints for a Laurentian connection, in Link, P.K. and Reed, S.L., eds, Proterozoic geology of western North America and Siberia: Society of Economic Paleontologists and Mineralogists Special Publication, v. 86, p. 209-226.

Kontorovich, A.E., Grebenyuk, V.V., Kuznetsov, L.L., Kulikov, D.P., Khmelevskiy, V.B., Azarnov, A.N., Nakaryakov, V.D., Polyakova, I.D., Sibgatullin, V.G., Soboleva, Ye.I., Starosel'tsev, V.S., and Stepanenko, G.F., 1994, Oil and gas bearing regions of the Siberia, Issue no. 3, Yenisei-Khatanga Basin (Neftegazonosnye basseyny i regiony Sibiri, vypysk 3, Yenisey-Khatangskiy basseyn): Novosibirsk, Russia, 71 p. (in Russian).

Kontorovich, A.E., Khomenko, A.V., Burshtein, L.M., Likhanov, I.I., Pavlov, A.L., Staroseltsev, V.S., and Ten, A.A., 1997, Intense basic magmatism in the Tunguska petroleum basin, eastern Siberia, Russia: Petroleum Geoscience, v. 3, no. 4, p. 359-369.

Kuznetsov, V.G., 1997, Riphean hydrocarbon reservoirs of the Yurubchen-Tokhom zone, Lena-Tunguska province, NE Russia: Journal of Petroleum Geology, v. 20, no.4, p. 459-474.

Lebchuk, M.A., 1990, Lithology and oil-gas prospects of Jurassic sediments of Yenisey-Khatanga downwarp: Petroleum Geology, v. 24, no.11/12, p. 309-326, translated from Novosibirsk, Izdatelstvo "Nauka," Sibirskoye Otdelenye no. 624, 165 p., 1985.
Persits, F.M., and Ulmishek, G.F., 2003, Maps showing geology, oil and gas fields, and geologic provinces of the Arctic: U.S. Geological Survey Open-File Report 97-470-J (CDROM).

Persits, F.M., Ulmishek G.F., and Steinshouer D.W., 1998, Map showing geology, oil and gas fields, and geologic provinces of the Former Soviet Union: U.S. Geological Survey OpenFile Report 97-470E, 1 CDROM.

Shenfil', V.Yu., 1991, The Late Precambrian of the Siberian Platform: Novosibirsk, Nauka Sibirskoye Otdelenie, 184 p.

Shishkin, B.B., and Isaev, A.V., 1999, Structure of the Precambrian and Cambrian deposits in the northeast of the Siberian platform: Russian Geology and Geophysics, v. 40, no. 12, p. 1795-1807 (in Russian), p. 1763-1775 (in English).

Surkova, V.S., 1987, Megakompleksy i glubinnoya struktura zemnoiy kory neftegazonosnykh provintsii Sibirskoyi Platformi: Moscow, "Nedra", Sibirskiy Nauchno-Issledovatelskiy Institut Geologii, Geofisiki i Mineralnogo Syrya (SNIIGIMS), 203 p. (in Russian).

Ulmishek, G.F., 2001a, Petroleum geology and resources of the Nepa-Botuoba High, Angara-Lena Terrace, and Cis-Patom Foredeep, southeastern Siberian Craton, Russia: U.S. Geological Survey Bulletin 2201-C, 16 p.

Ulmishek, G.F., 2001b, Petroleum geology and resources of the Baykit High Province, East Siberia, Russia: U.S. Geological Survey Bulletin 2201-F, 18 p.

Ulmishek, G.F., and Klemme, H.D., 1990, Depositional controls, distribution, and effectiveness of world's petroleum source rocks: U.S. Geological Survey Bulletin B-1931, 59 p.

Zonenshain, L.P., Kuzmin, M.I., and Natapov, L.M., 1990, Geology of the USSR; a plate-tectonic synthesis, in Page, B.M., ed., Geodynamics Series, v. 21, 242 p. 


\section{Appendix. Input data for the Tunguska Basin Assessment Unit}

Appendix file is available online only, and may be accessed at https://doi.org.10.3133/pp1824U. 
